\title{
Electrochemical Oxidation of Phenyl Hydrazine
}

\author{
Shilpi Saxena* ${ }^{1}$, Manika Barar ${ }^{2}$ \\ ${ }^{* 1}$ Department of Chemistry, C.C.S. University, Meerut, 250004 (U.P.) India \\ ${ }^{2}$ Department of chemistry, C.C.S.U Meerut, 250004 (U.P) India
}

\begin{abstract}
The electrochemical oxidation of Organic pollutant has been studied at solid micro electrodes over a wide $\mathrm{pH}$ range. Phenyl hydrazine exhibited a single anodic diffusion controlled and irreversible peak during cyclic voltammetric studies. Voltammograms were recorded prior to electrolysis at different $\mathrm{pH}$, scan rates and concentrations. The redox behaviour of the compounds was studied to have the optimum experimental conditions for their degradation and to find out the decrease in toxicity in the breakdown products of the degradation. The purpose of the present study is to address the issue by investigating the performance of electrochemical treatment for the removal of toxicity.
\end{abstract}

\section{Introduction :}

Phenyl hydrazine is a chemical intermediate for explosives, heat stabilizers, textiles, agricultural chemicals, dyes and pharmaceuticals. It is a reducing agent for many transition metals. ${ }^{[1]}$

Amines are not readily adsorbed onto the non-polar carbon surface. The amine must first be degraded and its degradation products adsorbed. Direct photolysis has not been found to be effective in the degradation of amines. Biological degradation is slow for many organic compounds and does not proceed at all for phenyl hydrazine. ${ }^{[2]}$

Electrochemical techniques for the treatment of pollutants offer many interesting possibilities because of their unique ability to decompose most resilent organic compounds at a well controlled electrode potential by just adding or withdrawing electrons. ${ }^{[3]}$

\section{Experimental :}

\section{Instrumentation}

Cyclic voltammograms were recorded on a EG\&G Princeton applied research Versastat-II Potentiostat. The platinum-working electrode was cleaned and activated using conc $\mathrm{HNO}_{3}$. After that working and auxiliary electrodes were shorted in conc $\mathrm{HNO}_{3}$. After that working and auxiliary electrodes were shorted in conc. $\mathrm{HNO}_{3}$ and scanned from $1.0 \mathrm{~V}$ to $-1.0 \mathrm{~V}$ for 100 seconds in chronoamperometric mode. ${ }^{[6,7]}$

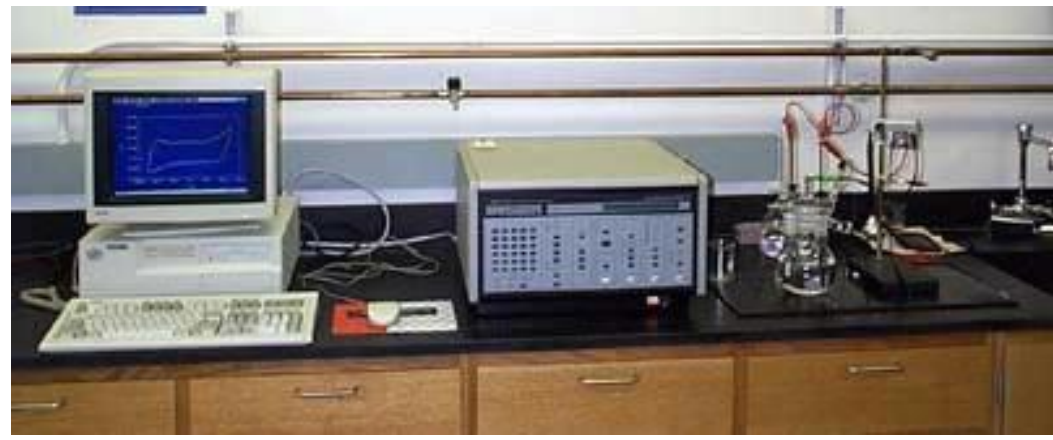

Fig. Cyclic voltameter

Controlled potential electrolysis (CPE) was carried on BAS CV -27 Cyclic voltammograph in connection with a Digital Electronics 2000 Omnigraph X-Y/t recorded. A three-electrode cell was used for the purpose. The cell consists of a glass container with a cap having holes for introducing electrodes and nitrogen gas. The working electrode is platinum foil $\left(3 * 3 \mathrm{~cm}^{2}\right)$, reference is $\mathrm{Ag} / \mathrm{Agcl}$ and auxiliary electrode a platinum wire which was directly poured in the solution.

The $\mathrm{pH}$ metric measurements were made on Hach EC 40 Bench top digital $\mathrm{pH}$ meter fitted with a glass electrode and saturated calomel electrode as reference, which was previously standardized with buffers of known $\mathrm{pH}$ in acidic and alkaline range. The reaction kinetics was studied with the help of uv-vis spectrophotometer(Elico SL-159). For measuring pollutional load of electrolysed solution,chemical oxygen demand(COD) of electrolysed solutions were determined. COD digestion apparatus (Spectralab-2015-S) was used for carrying out the experiment. 


\section{Procedure}

For cyclic voltammetry (CV) and controlled potential electrolysis (CPE) solutions were prepared by mixing $7.0 \mathrm{~mL}$ of the stock solution and $1.0 \mathrm{~mL}$ of $1.0 \mathrm{M} \mathrm{KCl}$ (as supporting electrolyte) and $2.0 \mathrm{~mL}$ of appropriate buffer. The solution was passed by nitrogen gas for $\sim 15$ minutes and, thereafter, a blanket of nitrogen gas was maintained throughout the experiment. After recording the cyclic voltammograms, the solution was subjected to controlled potential electrolysis. ${ }^{[8]}$

For coulometric determination of number of electrons " $n$ " involved in the oxidation ,solution was prepared in the similar fashion as for cyclic voltammetric studies.

\section{Cyclic Voltammetry}

\section{Results \& Discussions}

Cyclic voltammetric studies carried out in distilled water and in buffers of different $\mathrm{pH}$. In distilled watwer two anodic peaks were observed at different scan rates $(20-100 \mathrm{mv} / \mathrm{s})$. Both the peaks are irreversible and diffusion controlled in nature. Irreversible nature of the electrode process is indicated by a positive shift in anodic peak potential with increasing scan rate $(20-100 \mathrm{mv} / \mathrm{s})$. With platinum foil as working electrode it took two hours of cpe for consecutive disappearance of peak(fig 1). ${ }^{[9]}$

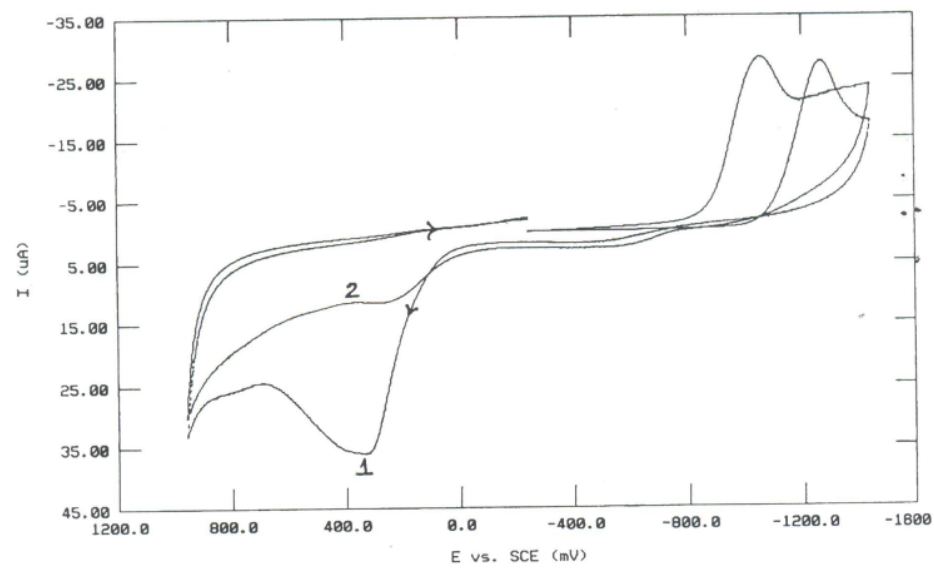

Fig1

Cyclic voltammograms of phenylhydrazine at glassy carbon electrode, $\mathrm{v}=20 \mathrm{~m} \mathrm{~V} / \mathrm{s}$

1. Befofe electrochemical treatment

2. After electrochemical reatment

Diffusion controlled nature of the electrode process is evident by the shift of peak potential with scan rate. Plot of ip,a Vs v1/2 is a straight line passing through the origin (fig 2).

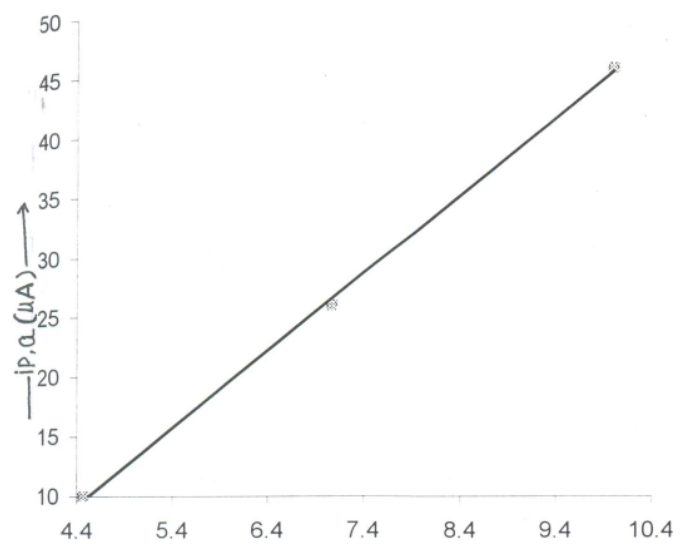

Fig. 2 
Plot of ip, a vs $\mathrm{v}^{1 / 2}$ of phenylhydrazine at glassy carbon etro, con $=4.5 \times 10^{-3} \mathrm{M}, \mathrm{pH}=10.5$

Electrochemical behavior of phenylhydrazine was also studied in buffers of different $\mathrm{pH}$. A significant anodic peak in acidic medium was observed while no cathodic peak could be observed in the $\mathrm{pH}$ range 2.5-12.0. A positive shift is observed in the anodic peak with increase in $\mathrm{pH}$ from 2.5-6.5. In basic medium anodic current decreased with increase in $\mathrm{pH}$ (Table1). On increasing the concentration of amine peak potential shifted towards more positive potential indicating irreversible nature of the electrode process. ${ }^{[10]}$

Table1: Electrochemical characteristics of phenyl hydrazine at different $\mathrm{pH}$ at $\mathrm{v}=100 \mathrm{mv} / \mathrm{s}, \mathrm{conc}=7 * 10$

\begin{tabular}{|c|c|c|c|c|}
\hline \multirow[t]{2}{*}{ pH } & \multicolumn{2}{|c|}{$\begin{array}{c}\mathbf{i p , a} \\
(\boldsymbol{\mu A} \mathbf{A})\end{array}$} & \multicolumn{2}{|c|}{$\begin{array}{c}\text { Ep,a } \\
\text { (v) }\end{array}$} \\
\hline & (i) & (ii) & (i) & (ii) \\
\hline \begin{tabular}{|r}
2.5 \\
\\
(1)A \\
(2) $\mathrm{B}$ \\
\end{tabular} & - & - & - & - \\
\hline $\begin{array}{ll} & 3.8 \\
& \text { (1) } \mathrm{A} \\
\text { (2) } \mathrm{B}\end{array}$ & $\begin{array}{l}80.55 \\
-\end{array}$ & $\begin{array}{l}155.0 \\
-\end{array}$ & $\begin{array}{l}0.11 \\
-\end{array}$ & $\begin{array}{l}0.87 \\
-\end{array}$ \\
\hline $\begin{array}{l}4.5 \\
\text { (1) A } \\
\text { (2)B }\end{array}$ & $\begin{array}{l}74.20 \\
-\end{array}$ & - & $\begin{array}{l}0.31 \\
-\end{array}$ & - \\
\hline $\begin{array}{l}5.6 \\
\text { (1) A } \\
\text { (2) } \mathrm{B}\end{array}$ & $\begin{array}{l}67.77 \\
-\end{array}$ & - & $\begin{array}{l}0.41 \\
-\end{array}$ & \\
\hline $\begin{array}{l}6.5 \\
\text { (1) A } \\
\text { (2) B }\end{array}$ & $\begin{array}{l}73.38 \\
-\end{array}$ & - & $\begin{array}{l}0.65 \\
-\end{array}$ & - \\
\hline $\begin{array}{l}7.9 \\
\text { (1) A } \\
\text { (2) } \mathrm{B}\end{array}$ & \begin{tabular}{|l|l|}
51.75 \\
-
\end{tabular} & - & $\begin{array}{l}0.39 \\
-\end{array}$ & - \\
\hline $\begin{array}{l}8.8 \\
\text { (1) } \mathrm{A} \\
\text { (2) } \mathrm{B}\end{array}$ & $\begin{array}{l}77.62 \\
-\end{array}$ & - & $\begin{array}{l}0.30 \\
-\end{array}$ & - \\
\hline $\begin{array}{l}10.5 \\
\text { (1) A } \\
\text { (2)B }\end{array}$ & $\begin{array}{l}76.49 \\
-\end{array}$ & - & $\begin{array}{l}0.3 \\
-\end{array}$ & - \\
\hline $\begin{array}{l}12 \\
\text { (1) } \mathrm{A} \\
\text { (2) } \mathrm{B}\end{array}$ & $\begin{array}{l}83.59 \\
-\end{array}$ & - & $\begin{array}{l}0.29 \\
-\end{array}$ & - \\
\hline
\end{tabular}

\section{A= Before electrochemical treatment}

$B=$ After electrochemical treatment

\section{Controlled potential electrolysis coulometry}

Controlled potential electrolysis of $1 * 10^{-3} \mathrm{M}$ solution of phenylhydrazine solution was carried out at $+0.90 \mathrm{~V}$ using platinum foil working electrode. With time anodic current decreased and gradually resulted in background current (fig 3). Coulometric measurements were carried out to calculate the number of elactrons involved in the overall electrode process and found to be $2 \pm 0.08$. Electrolysis time for complete removal of toxicity extended up to 2 hours at a concentration of $1 * 10^{-3} \mathrm{M}$.

\section{Chemical oxygen demand}

COD of initial and electrolysed solutions were determined and it was observed that COD values show a significant decrease from $3600 \mathrm{mg} / \mathrm{L}$ to $1880 \mathrm{mg} / \mathrm{L}$, indicating less toxicity of the oxidized product.

\section{References}

[1]. O. Hammerich and Svensmark, Dekker, New York, $3^{\text {rd }}$ ed..,chapter 16 (1991).

[2]. E.Santos and M.C Giordano, Electrochim. Acta, 30 (1985) 871

[3]. D.G Peters, Dekker, New York, $3^{\text {rd }}$ ed...chapter 8(1991).

[4]. K.Mortelmans, and E.Zeiger., Mutal res, 2000 Nov 20,455.

[5]. APHA, AWWA, WET, standard methods for the examination of water and waste water, American public health association publication, Washington DC (1995).

[6]. P.Rys and H Zollinger, Fundamental of the chemistry and the application of the pollutant (1972).

[7]. J.bandra, V.Nadtochenko, J.Kiwi and C. Pulgarin, wat.Sci. Tech ,35 (1997).

[8]. R.H Wopschall and I . Shain, Anal. Chem.,39 (1967).

[9]. S.Nam and P.G Trantnyek, wat. Res , 34(2000) 1837.

[10]. K.C.A Bromley challenor, J.S Knapp,Z.Zhang, N.C.C Gray, M.J Hetheridge and M.R Evans, Wat.Res ,34 (2000) 4410. 